Dokuz. Eylül Üniversitesi

İlahiyat Fakeültesi Dergisi

2015/1, Sayn 41, ss. 189-212.

\title{
TEFSÎRDE KİTAB-I MUKADDESİN TAHRÎFİ MESELESİ: I ( Tahrîf Kelimesi Bağlamında)
}

Ferruh KAHRAMAN*

ÖZET

Günümüz toplumunda globalleşmenin bir sonucu olarak, farklı din ve kültüre ait toplumların bir arada yaşaması ve sağlıklı iletişim kurmaları daha da zorunlu hale gelmiştir. Sağlıklı bir iletişim de bu dinlerin birbirlerini daha yakından tanımaları ile mümkün olacaktır. Bu çalışmada ilk dönemlerden itibaren çok önemli bir yere haiz olan tahrîf meselesinin, tefsîr eserlerinde ve özellikle son dönem Türk müfessirleri tarafından nasıl ele alındığı, doğrudan tahrîf ifadesinin geçtiği dört âyet merkeze alınarak incelenmiştir. $\mathrm{Bu}$ dört âyetin değerlendirilmesi sonucunda anlaş1lır ki Yahûdîler kendilerine indirilen vahyi belli ölçüde tahrîf etmişlerdir. Kitab-1 mukaddes'in tahrîfi, tefsîr ilminde lafız, manâ ve hem lafız hem de manâ ve kısmî lafız ve manâ olmak üzere başlıca dört şekilde yorumlanmıştır.

Anahtar kelimeler: Tefsîr, tahrîf, problem, lafiz, manâ

\section{THE ISSUE OF CORRUPTION OF HOLY BOOKS IN TAFSEER: I (In the Context of the Word of Corruption)}

\section{ABSTRACT}

Under the effect of globalization in today's World, it is becoming clear that there is a necessity of the proper communication among the people from various religions and cultures living together. Setting a proper and healthy communication is only possible with knowing each other. In this study, how early scholars and recent Turkish exegesis scholars interpreted the word of "corruption" is examined in the context of four verses of the Quran which includes the word of "corruption". Since the four verses have been evaluated, it seems that Jews corrupted the revelation revealed to them. The exegesis scholars state that Torah was corrupted in three major ways: Text, Meaning and both text and meaning. However all three ways are not valid for whole sacred texts, but for parts of the texts.

Key words: Exegesis, corruption, problem, text, meaning

* Yrd. Doç. Dr., Dokuz Eylül Üniversitesi, İlahiyat Fakültesi, Arap Dili ve Belağatı ABD Öğretim Üyesi. 


\section{GİRİ̧̧}

Kur'ân'da Ehl-i kitabın Tevrât ve İncîl gibi kutsal kitaplara karşı menfî tavır ve yaklaşımları bildirilir. Bu konuda son dönemde bir hayli çalışmalar göze çarpmaktadır. ${ }^{1}$ Tahrîf meselesi açı bir şekilde bizzat "tahrîf" kelimesiyle ifade edildiği gibi; bunun yanında eş anlamlıları olan "tebdîl", "kıtmân", "leyy", "lebs" ve "nisyân" lafızlarıyla da ifade edilir. Bu makalede tahrîfin müradifleri hakkında kısa bir açıklama yapildıktan sonra daha detaylı yorumlar bir sonraki makaleye havale edilmiştir. Burada tahrîfin sarih olarak geçtiği âyetler bağlamında değerlendirme yapılmıştır. Değerlendirmelerde de kısaca ilk dönemden itibaren önemli kabul edilen farklı tarih ve coğrafyaya ait müfessirlere müracaat edilmiştir. Fakat son dönem Batıyla temas sonucunda Türk müfessirlerinin seleflerinden ayrllıp ayrılmadıklarını anlamak için son dönem Türk müfessirlerine daha fazla yer verilmiştir. Belli bir dönemle sinırlandırılmamasındaki gaye, tarih boyunca tahrîfin nasıl algılandığı ve ilk dönemle son dönem arasındaki farkların olup olmadığının tespit edilmesidir.

Dört bölümden oluşan bu makalenin birinci bölümünde Kur'ân'da Tevrât ve İncîl; ikinci bölümde tahrîf ve tahrîf kelimesinin geçtiği âyetler üzerinde durulmuştur. Tahrîf in Arapçada hangi anlamlara geldiğini tespit etmek, tahrîfatın boyutlarını anlamak amacıyla yapılmıştır. Üçüncü bölümde tefsîrde tahrîfin şekli ile ilgili yaklaşımlar ortaya konmuş, son bölümde ise tahrîfle ilgili âyetlerin müfessirlere göre yorumları değerlendirilmiştir. Son bölümde takip edilen metot âyetlerin tertip sırasına göre başlıklar halinde tek tek ele alınması şeklinde olmuştur.

\footnotetext{
1 Konuyla ilgili tartışmalar için bkz. Goldziher, Ignaz, "Ehl-i Kitaba Karşı İslâm Polemiği I" çev. Cihad Tunç, Ankara İlahiyat Fakültesi İslâm İlimleri Enstitïiü Dergisi, sy. 4, Ankara 1980, s. 151-170; Goldziher, Ignaz, "Ehl-i Kitaba Karşı İslâm Polemiği II" çev. Cihad Tunç, Ankara İlabiyat Fakültesi İslâm İlimleri Enstitüsü Dergisi, sy. 5, Ankara 1982, s. 249- 278; Adam, Baki, Yabûdî Kaynaklarnna Göre Tevrât, Pınar Yay., İstanbul 2001, s. 208-232; Adam, Baki, "Kur'an'ın Anlaşılmasında Tevrât'ın Rolü”, İslâmî Araştırmalar Dergisi, c. 9, sy. 1- 4, Ankara 1996, s. $167-$ 176; Adam, Baki, "Tevrât'ın Tahrîfi Meselesine Müslüman ve Yahûdî Cephesinden Bir Bakış", Ankara İlabiyat Fakültesi Dergisi, sy. 36, Ankara 1997, s. 359-404; Gökkır, Necmeddin, "Kur'ân-1 Kerîm Açısından İlahî Kitapların Tahrîfi Meselesi”, İstanbul Üniversitesi İlabiyat Fakültesi Dergisi, sy. 2, İstanbul 2000, s. 221-256; Gaudeul, J.M. - R. Caspar, "Kitab-1 Mukaddes'in Tahrîfi Konusunda Klasik İslami Kaynakların Yaklaşımı”, çev. Ali Erbaș, Sakarya Üniversitesi Illahiyat Fakültesi Dergisi, sy. 7, Sakarya 2003, s. 131-167; Biçer, Ramazan, İslâm Kelâmclarnna Göre İncîl, Gelenek Yay., İstanbul 2004, s. 87 ve devamı. Tarakç1, Muhammed, "Tevrât ve İncîl'in Tahrîfi ile İlgili Kur'ân Âyetlerinin Anlaşılması Sorunu" Usûl Dergisi, sy. 2, Adapazarı, 2004, s. 33-53; Yıldırım, Arif, "Kelamî Açıldan Tevrât ve İncîlde Tahrîf Meselesi”, Atatürk Üniversitesi İlahiyat Fakültesi Dergisi, sy. 26, Erzurum 2006, s. 11 26; Yavuz, Salih Sabri-Yeniçağ, İbrahim, "Müslüman-Hıristiyan Polemiği Açısından Tahrîf", Milel ve Nihal, cilt 6/sy 1, y. y. Nisan 2006, s. 305-344.
} 


\section{A. KUR'ÂN'DA TEVRÂT VE İNCÎL}

Tevrât kelimesi Kur'ân'da toplam on altı âyette on sekiz defa zikredilir. Bunlarında çoğu da Yahûdî ve Hiristiyanlardan sıkça bahsedilen Âl-i İmrân ve Mâide sûrelerinde geçmektedir. Âl-i İmrân sûresindeki âyetlerde, Allah'in Kur'ân'dan önce Tevrât ve İncîl'i inzâl ettiği; Îsâ'ya Tevrât ve İncîl'in öğretildiği; Hz. Îsâ'nın Tevrât'ı doğrulamak üzere gönderildiği belirtilmekte ve Yahûdîlere meydan okunmaktadır. ${ }^{2}$ Mâide sûresinde ise, Tevrât'ta Allah'ın hükmünün, rehberlik ve nurun, kısas emrinin bulunduğu; Hz. Îsâ’nın Tevrât'’ doğrulamak üzere gönderildiği ve kendisine Tevrât'in öğretildiği; İncîl'in, Tevrât'’ tasdik ettiği açıklanır. Yine aynı sûrede, Ehl-i kitab'nn, kendi kutsal kitapları olan Tevrât ve İncîl’i uygulama noktasında kusur gösterdikleri belirtilir. Ehl-i kitaba Tevrât, İncîl ve Rablerinden kendilerine indirileni uygulamaları emredilir. ${ }^{3}$ Tevrât kelimesinin geçtiği diğer âyetlerde ise, müminlerin Tevrât'ta nasil tasvir edildikleri, Hz. Îsâ'nın Tevrât'ı tasdik ettiği ve Tevrât'1 tatbik etmeyenlerin durumu açıklanır. ${ }^{4}$

İncîl Kur'ân'da on iki defa geçmektedir. Örneğin Âl-i İmrân sûresinde Tevrât, İncîl ve Furkân'ın inzâl edildiği; Kur'ân'’n ise kadim kitapları onaylamak üzere indirildiği bildirilir. ${ }^{5}$ Mâide sûresinde, İncîl'in, Tevrât'1 tasdik ettiği, Hz. Îsâ’ya verildiğgi belirtilir ve ona ittiba emredilir. ${ }^{6}$ Ona gereği gibi ittiba etmeyenlerin ise doğru yolda olamayacaklarına vurgu yapılır. ${ }^{7}$ A'râf sûresinde Tevrât ve Incîl'de Hz. Peygamber ile ilgili işaret ve ifadelerin bulunduğu belirtilir. ${ }^{8}$ Tevbe ve Fetih sûrelerinde Tevrât, İncîl ve Kur'ân'da yer alan müşterek içerikten bahsedilir. ${ }^{9}$ Saff sûresinde ise açıkça Hz. Îsâ’nın, kendisinden sonra gelecek ve ismi Ahmed olan bir peygamberi müjdelediği belirtilir. ${ }^{10}$ Kur'ân-1 Kerîm'de, Hz. Îsầya bir kitap verildiği sarahaten geçer. ${ }^{11}$ Hal böyle olmakla beraber Kur'ân'da Tevrât ve İncîl'in isminin zikredildiği âyetlerde doğrudan tahrîfle ilgili ifadeler bulunmamaktadır. Dolayısıyla Tevrât ve İncil'in tahrîf edilip edilmediğini anlamak için meseleye muhataplar açısından yaklaşmak gerekecektir.

\footnotetext{
Âl-i İmrân 3/3, 48, 50, 65, 93.

Mâide 5/43-46, 66, 68, 110.

Fetih 48/29; Saff 61/6; Cuma 62/5.

Âl-i İmrân 3/3.

Mâide 5/46, 47.

Mâide 5/66, 68.

A'râf 7/157.

Tevbe 9/111; Fetih 48/29.

Saff 61/6.

11 Meryem 19/30.
} 


\section{B. TAHRÎF VE TAHRÎF KELIMMESİNIN GEÇTİĞİ ÂYETLER}

Bu bölümde tahrîf ve tahrîfle ilgili kelimelerin lügat anlamları üzerinde durulup hangi anlamlarda kullanıldıkları incelenecektir. Ayrıca tahrîfle yakın anlamlı olan kelimelerin Kur'ân'da hangi anlamda kullanıldığına kısaca değinilecektir. Kur'ân'da tahrîfle yakın anlamlı kullanılan kelimelerin başında "tebdîl", "kitmân", "leyy", "lebs" ve "nisyân" gelmektedir. Ancak burada tahrîf kelimesinin daha iyi anlaşılması için sadece tahrîf kelimesi üzerinde durulacaktır. Bir sonraki makalede de "tebdîl", "kitmân", "leyy", "lebs" ve "nisyân" gibi kelimeler incelenecektir.

\section{Tahrîf}

Tahrif, Arapça h-r-f/ حَرَف kökünden türemiştir. Harefe lügatte, "bir şeyin kenarı, köşesi ve ucu" anlamlarına gelmektedir. Aynı kökten türetilmiş tefîl babının mastarı olan tahrîf kelimesi "bir şeyin yerinin değiştirilmesi, şekilde ve lafızda bozukluk" anlamlarına gelmektedir. ${ }^{12}$ Bir başka babdan kullanımı olan inhirâf ise "tahrîf olma, bozulma, eğilme, dönme, yanlış yöneliş ve sapkınlık" gibi anlamlara gelmektedir. ${ }^{13}$

Tahrîfin en yaygın manâsı, bir şeyin yer ve konumunu değiştirmektir. Dolayısıyla bu kökten türeyen kelimeler Kur'ân-1 Kerîm'de, Ehl-i kitabın kutsal kitaplarını tahrîf etmesiyle alakalı olarak dört yerde geçmektedir. ${ }^{14}$ Mezkûr kelime, âyetlerde Yahûdî ve münafikların kelime ve harfleri benzerleriyle değiştirdiklerini ifâde eder. Bundan dolay1 Ragıb el-İsfehânî, (ö. 502/1109) tahrîfi "hem yazıda hem de sözde olan değișiklik"15 olarak tanımlarken Râzî (ö. 606/1209) de "bir yazı ve sözün asli manâsının değiştirilerek bozulması" şeklinde açılama getirmiştir. ${ }^{16}$ İbn Manzûr'a (ö. 711/1311) göre kelimeyi yerinden tahrîf etmek, kelimeyi değiştirmektir. Kur'ân'da ve kelimede tahrîf, harfin ve kelimenin manâsını benzeriyle değiştirmektir. ${ }^{17}$ Elmalılı (ö. 1942) ise söz konusu âyetin "bile bile veya kasden manâsını değiştirecek şekilde kelime ve harflerin yerlerinden oynatılması" anlamlarına geldiğini ifâde etmiştir. ${ }^{18}$

12 İsfehânî, Ragıb, Müfredât, Safvân Adnan, Dâru'l-kalem-ed-Dâru'ş-şamiyye, Dımeşk-Beyrut 1412, I, 228; İbn Manzûr, Lisânü'l-Arab, Dâru sâdır, Beyrut 1414, IX, 43.

13 İsfehânî, Müfredât, I, 228; İbn Manzûr, Lisânü'l-Arab, IX, 43.

14 Bakara 2/75; Nisâ 4/46; Mâide 5/13, 41.

15 İsfehânî, Müfredât, s. I, 228.

16 Râzî, Fahruddîn, Mefâtîhu'l-ğayb, Dâru ihyâi'l-türâsi'l-Arabî, Beyrut 1420, XI, 359.

17 İbn Manzûr, Lisânü'l-Arab, IX, 43.

18 Elmalılı, Hak. Dini Kur'ân Dili, Azim Yay., İstanbul ts., I, 327; VI, 246. 
Çağdaş müfessirlerden Reşid Rıza (ö. 1935) ise tahrîfin iki anlamına dikkat çekmektedir:

a) Gerçek anlamını bozacak şekilde sözü tevil etmektir. Âyette geçen "mevâdı" " ile kastedilen de "meânı̂", yani sözün anlamıdır. Bu durumda âyet, "Onlar kelimeleri gerçek anlamlarmdan uz̧aklaştrryorlar" manâsına gelmekte ve Yahûdîlerin Hz. Peygamber'in nübüvvetini inkâr etmek için yaptıkları yorumlara işaret etmektedir.

b) Tahrîfe yüklenen ikinci anlam, Tevrât'ta bazı kelimelerin yerlerinin değiştirilmesidir. Bu tür bir tahrîfin varlı̆̆ını, Ehl-i kitap’tan bazı kimseler de kabul etmekte ve bunun Tevrât'ı düzeltmek için yapıldığını savunmaktadırlar. ${ }^{19}$

Tahrîf, yazılı bir metnin doğrudan doğruya değiştirilmesi, metinden bazı kısımların çıkarılması veya ona ilaveler yapılması, bir metni okurken keyfi olarak değiştirilmesi ya da metnin tefsîr ve te'vîllerle maksadının dışında başka anlamla açıklanmasıdır. Sonuç olarak şunları söylemek mümkündür: Yukarıda da özetlendiği gibi tahrîf bazen lafız bazen de manâ ağırlıklı yorumlanmıştır. Bu yorumlar1 yapan her iki grup da tahrifin hem yorumda hem de metinde yapıldığını kaydetmektedir. Bununla beraber bazıları tahrîfi benzer ifadelerle yapılan değişiklikler olarak algilarken diğerleri tamamen farklı anlamlara kaydırmak şeklinde yorumlamaktadır.

\section{Kur'ân'da Tahrîf Kelimesinin Geçtiği Âyetler} geçmektedir:

Kur'ân'da tahrîf kelimesi Yahûdîlerle ile ilgili olarak dört yerde

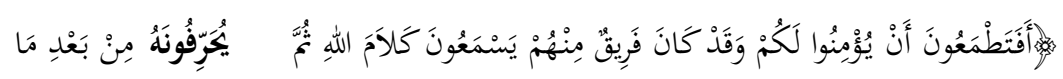

“Nasil olur onlarm size güvenmelerini beklersiniz ki onlardan bir zümre vard ki Allab'n kelamın işitip akıllarn ald1ktan sonra, bile bile onu tahrîf eder, değģstivirlerdi". ${ }^{20}$

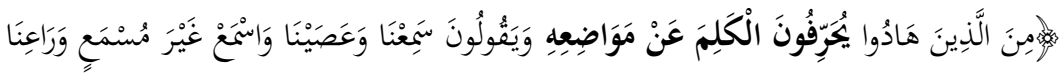

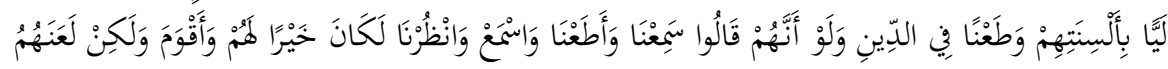

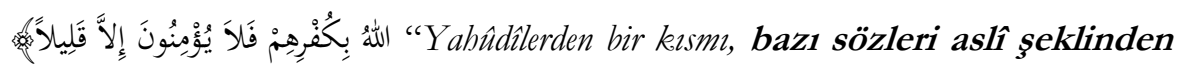

ve manâsından saptırır, mesela: "İsittike" (ama isyan ettik), "işit" (bay işitmez olası!), ve râina derler. Bu sö̊leri, ağ̌zlarm eğip bükerek güya vaziyeti kurtarmak ve dinle alay etmek için söylerler. Halbuki onlar sadece "İ̧ittik ve itaat ettike", "Sende bizi işit!" un₹urnâ

19 Muhammed Abdüh-Reşid Rızâ, Tefsiru'l-menâr, Dâru'l-ma'rife, Beyrut ts, V, 140.

20 Bakara 2/75. 
(bizi de gözet!'), deselerdi kendileri için elbette daha bayırl ve daha dürüst bir iş olurdu. Fakat Allah, inkârlar yüzünden onlar rahmetinden kovdu. Artı onlar pek az iman ederler". ${ }^{21}$

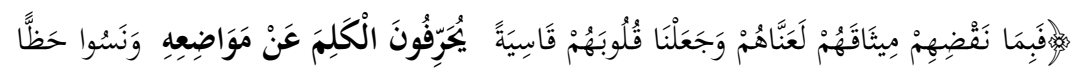

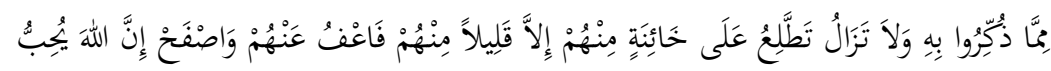

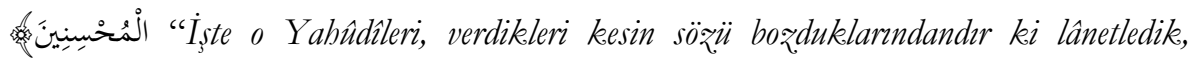
onlarn kalplerini katılasttrdlk. Böylece onlar kelimeleri yerlerinden oynatarak tahrîf ederler. Kendilerine tebliğ edilen hususlardan pek çoğunu unuttular. Onlarn pek až hariç olmak üzere, onlar tarafindan devaml olarak bainlik, görürsün. Yine de sen onlar affet, aldrrma! Cü̈nkü Allah iyilike edenleri sever". ${ }^{22}$

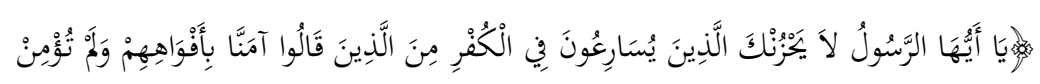

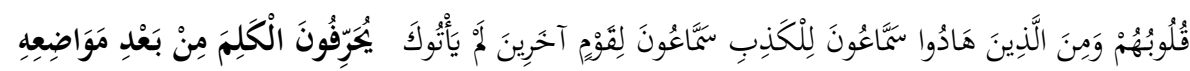

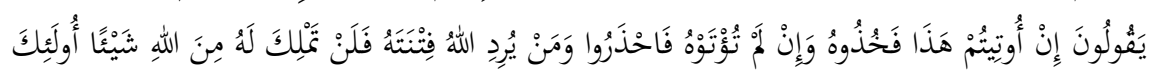

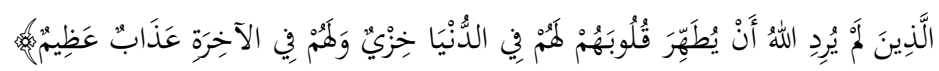

"Ey Peygamber! Kalpleri iman etmediği halde ağzlaryla "iman ettik" diyen münafiklarla, Yabûdîlerden kâfirlikete yarısanlar seni üzmesin. Zira onlar yalanculı etmek için dinlerler. Senin yanında olmayan bir grup besabına casusluk için dinlerler. Kelimeleri konuldukları yerlerden çıkarıp tahrîf ederler. "Size şu fetva verilirse onu kabul edin, o verilmezse kabul etmekten geri durun" derler. Allab birini sastrtmak isterse, sen onun lebinde Allah'a karşı hiçbir şey yapamazsın. Onlar öyle kimselerdir ki Allah onlarn kalplerini arndirmak istememiştir. Onlarm bakke dünyada rüsvayllk olduğu gibi, âhirette de müthis bir cezadir". 23

Birinci âyette Allah kelâmı'nın tahrîf edildiği söylenmektedir. İkinci, üçüncü ve dördüncü âyetlerde tahrîf kelimesi, bir kelime grubunun parçası olarak kullanılmış ve "kelimelerin mevailerinden tahrîf edildiğì" belirtilmiştir. Bu âyetlerde geçen "tahrîf" kelimesi müfessirler tarafindan farklı şekilde yorumlanmıştır. Müfessirlerin geneline göre, sözün tahrîfi veya "kelimelerin عَنْ مَوَاضِعِدِ/mevilerinden tahrîf edilmesi”, sözün farklı bir şekilde yorumlanması,

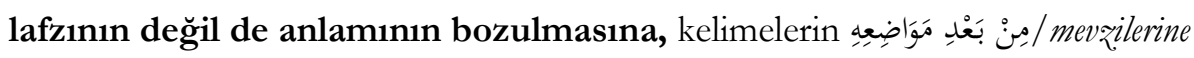
konulduktan sonra ifadesi" ise lafżn değiştirilmesine işaret eder. Buna göre

21 Nisâ $4 / 46$.

22 Mâide 5/13.

23 Mâide 5/41. 
yukarıda geçen dört âyet, Yahûdîlerin, kendi kitaplarını kasten yanlış yorumladıklarını açıklamaktadır.

\section{TEFSÎRLERDE TAHRÎFIN ŞEKLİ İLE İLGİLI} YAKLAŞIMLAR

Kur'ân-1 Kerîm'de; Yahûdîlerin kutsal kitaplara karşı menfî tavırları açıcça ifade edilir. Dolayısıyla bu konuda tefsîrde de aksi görüşlere rastlanmaz. Ancak tahrîfin mâhiyeti konusunda bazı farklı ve aykırı görüşler vardır. Tefsîrin ilk dönemlerinden bu yana mezkûr konu, lafiz ve manâ bağlamında ele alınmıştır. Dolayısıyla değişik görüşlerin ve ihtilafın oluşmasına yol açan husus, tahrîfin lafizla mi yoksa manâ ile mi yoksa her ikisiyle mi olduğudur. Kimi alimlere göre bu konu Kur'ân'da açık değildir. Tekrar hatırlanacağı üzere tahrîf, yazılı metnin doğrudan doğruya değiştirilmesi, metinden bazı kısımların çıkarılması veya metne ilaveler yapılması, doğru olan bir metnin okunurken keyfi olarak değiştirilmesi ya da metnin yanlış tefsîr edilmesi gibi değişik şekillerdedir. ${ }^{24}$ Tahrîfin şekli ve gruplandırmasında alimler arasında bir ittifak yoktur. Mesela, bazı araştırmacılar İbn Haldun'un (ö. 808/1406) manâ tahrîfini savunduğunu söylemektedirler. Onun yazılarına bütüncül olarak bakıldığında öyle olmadığ1 görülecektir. ${ }^{25} \mathrm{Bu}$ çalışmadaki tasnif ve gruplandırmalarda muadil çalışmalarıyla bazı farklılıklar olacaktır. Ancak biz müelliflerin görüşlerini değerlendirirken bütüncül ve geniş kapsama dikkat etmeye ve kararımızı ona göre vermeye çalıştık. Buna bağlı olarak alimlerin bu konudaki görüşlerini dört grupta toplamak mümkündür.

1- Bazı alimler, Yahûdîlerin doğrudan doğruya kitaplarının metnini bozduklarını ileri sürerler. Bu görüss $\mathrm{Hz}$. Peygamber'den sonraki asırlarda hakim olan görüştür. ${ }^{26} \mathrm{Bu}$ görüşün kuvvetli bir temsilcisi Endülüs'lü İbn Hazm (ö. 456/1063)'dir. ${ }^{27}$ İbn Hazm, lafzî tahrîfle ilgili “ilk havari şeçimleri”" ve "Jaire'nin kızının dirilişı”yle alakalı İncîller arasındaki çelişkileri ele alır. ${ }^{28}$ Lafzî̀ tahrîfi savunan alimlerin en önemlilerinden biri de Cüveynî (ö.478/1085)'dir. ${ }^{29}$ Cüveynî lafzî tahrîfe daha fazla örnek vermiştir. Ona göre en önemli çelişkili konular: "Îsâ"nın soy kütüğ̈̈, Petrusun inkarı, Kudüs'e görkemli giriş, Îsầ"nın

24 Mâtürîdî, Ebû Mansur, Te'vîlâtü ebli's-sünne, Müessesetürr-risâle, Beyrut 2004, I, 285; Râzî, Fahruddîn, Mefâtîhu'l-ğayb, XI, 359; Zemahşerî, Ebû Kasım Mahmûd b. Ömer, el-Keşşâf an bakâik ğavâmidi't-teñîl ve'l-uyunni'-avâni'l fì vücûhi't-te'vîl, Dâru ihyâi't-türâsi'l-Arabiyye, Beyrut 1997, I, 548, 549; I, 666; Elmalıl, Hak Dini Kur'ân Dili, I, 327; III, 246.

25 Bkz. İbn Haldun, Kitâbü'l-iber, Dâru'l-kitâbi'l-Lübnânî, Beyrut 1956, II, 10, 11.

26 Her ne kadar bu görüş, Hz. Peygamber (s.a.s)'den hemen sonra hakim olsa da bu konuda sistematik araştırmalar daha sonraki dönemlere rastlar.

27 İbn Hazm, Kitâbü'l-fasl, Matbaatü'l-Edebiyye, y.y , Kahire 1902, II, 18-21.

28 Bkz. İbn Hazm, Kitâbü'l-fasl, II, 18-26

29 Cüveynî, Şifâü'l-ğalil, thk. Michel Allard, Dâru'l-meşrrk, Beyrut 1968, s. 66, 67. 
çarmıha gerilişi ve ölümü"dür. ${ }^{30}$ Taberî (ö. 310/923) de tahrîfe yakın anlamlı kelimeleri tefsîr ederken benzer şeyler söyler. ${ }^{31}$ Lafiz tahrîf olduğu için dolaylı olarak yorum da tahrîf olacaktır. Bu ilk görüş aynı zamanda hem lafız hem de manâyı kapsamaktadır. Lakin bunlar tahrîfin daha çok lafizda olduğunu savunmaktadırlar. Yani öncelikleri metin tahrîfidir.

2- Bazı müfessirler de hem lafiz hem de manâ tahrîfini kabul edip genel bir değerlendirme yaparlar. Bu görüşü savunan müfessirler, Yahûdî ve Hiristiyanların metinlerindeki tahrîfin her iki şekilde de olduğunu ifade ederler. Mâtürîdî (ö. 333/944) ve Zemahşerî (ö. 538/1143) gibi alimler bu gurupta değerlendirilebilir. ${ }^{32}$

3- $\mathrm{Bu}$ görüşe tamamen zit olan diğer bir görüş ise kitap ehlinin elinde bulunan metinler sahihtir. Tahrîfin bu metinlerin yanlış tefsîrinden vuku bulduğunu savunan Makrîzî, (ö. 845/1442) tahrîfin Tevrât'la ilgili olmayip onun şerhleri olan Mişna olduğunu söyler. ${ }^{33} \mathrm{Bu}$ görüşün son dönem temsilcileri arasında Muhammed Abdüh (ö. 1905) sayılabilir. Muhammed Abdüh de Tevrât ve İncili, müntesipleri tam olarak anlayamadıkları için manen tahrîf etmişlerdir demektedir. ${ }^{34}$ Kısmen de olsa bu görüşü Dihlevî (ö. 1176/1762) de savunmaktadır. Onunla ilgili kısmen diyoruz çünkü o, tahrîfin yorumda olduğunu iddia ederken bozulmanın daha sonra tercümelerde olduğunu söyler. ${ }^{35}$ Bu âlimlerin en önemli delillerinden birisi "Yahûdî ve Nasara kendi kitaplarını tefsîr etmek suretiyle tahrîf ettiler ve onlar açıklayamadıkları bölümleri ise gizlediler" ifadesidir. ${ }^{36}$

4- Tahrîfin lafız ve manâ olmak üzere kısmî olduğu bu kısmîlikte de manâ tahrîfinin lafizdan daha çok olduğudur. Bu görüş, üçüncü maddeyle biraz yakın olsa da kısmî ve cüzî bir tahrîfi savundukları için mutlak anlamdaki lafız ve manâ tahrîfinden ayrılır. Bu iddia, İbn Sinâ (ö. 428/1037) ${ }^{37}$ gibi kimselerin görüşüdür ki daha sonraki temsilcilerinden biri İbn Haldun (ö. 808/1406)'dur. ${ }^{38}$ İbn Haldun bu görüşün muahhar taraftarlarından olup;39

30 Bkz. Cüveynî, Şifäül-ğalil, s. 70-83.

31 Taberî, Câmiü'l-beyân, Müessesetü’r-risâle, Beyrut 2000, I, 568.

Bkz. Mâtüridî, Te'vîlâtü ehli's-sünne, I, 285; Zemahşerî, Keşşâf, I, 548, 549; I, 666.

Makrîzî, Ahmed b. Ali, Hitat el-Makrîzî, y.y. Kahire 1270, s. 475.

Abdüh, Tefsîru'l-menâr, II, 159, 160.

35 Dihlevî, Şah Veliyyullah, Fevฉü̈l-kebîr, çev. Mehmet Sofuoğlu, Çağrı Yay., İstanbul 1980, s. 13.

36 Bkz. Dârimî, Sünen, "Mukaddime” 56, y.y., Dimeşk, 1930, I, 163.

37 Bkz. İbn Sina, er-Risâletü'l-edhaviyye fi'l-meâd, y.y., 1969, s. 58, 59. Ancak İbn Sinâ burada k1smî bir anlam tahrîfinden söz etmektedir.

38 İbn Haldun, Kitâbü'l-iber, II, 10, 11. 
kaynağını İbn Abbas’a dayandırmaktadır. ${ }^{40}$ J.M. Gaudeul ve R. Caspar müşterek yazdıkları makalede İbn Sinâ ve İbn Haldun'un teville tahrîfi savunduklarını söylemektedirler. Esasında onlar, kısmî lafız ve manâ tahrîfini savunmaktadırlar. ${ }^{41}$ Kısmî tahrîfi savunan başka bir alim de İbn Teymiyye (ö. 728/1328)'dir. Ona göre kutsal kitaplar tahrîf olsa bile bu kısmîdir. İçlerinde Allah'ın hükümlerini içeren çok âyet vardır. ${ }^{42}$ Müfessirlerden Râzî, ${ }^{43}$ Elmalılı (ö. 1942) ${ }^{44}$ ve Ateş ${ }^{45} i$ de bu guruba dahil edebiliriz.

\section{MÜFESSİRLERİN TAHRÎFLE İLGİLİ GÖRÜŞLERİ}

Bu bölümde; tahrîfle ilgili âyetlerin hangi manâya hamledildiğini anlamak için müfessirlerin yorumları değerlendirilecektir. Müfessirlerin, âyetleri nasıl değerlendirdikleri, nasıl yorumladıkları göz önünde bulundurularak, tahrîf konusundaki görüşleri anlaşılmaya çalışlacaktır. Tahrîfin geçtiği âyetler guruplandırllip, her âyet müfessirlere göre incelenecektir.

Kur'ân-1 Kerîm'de tahrîf kelimesine bakıldığında mezkûr kelimenin Bakara ve Nisâ sûrelerinde birer âyet, Mâide sûresinde ise iki âyet olmak üzere toplam dört âyette geçtiği görülecektir. Bu çalışmada tahrîf kelimesi sûre başlığ1 altında fakat tahrîfin geçtiği âyet özelinde ele alınacaktır. Tasnifte mevcut Mushaf tertibi dikkate alınarak Bakara, Nisâ ve Mâide sûresi şeklinde sıralama yapılmışır.

\section{Bakara Sûresi 2/75. Âyeti Etrafında Yapılan Yorumlar}

Kur'ân-1 Kerîm'de tahrîfle ilgili âyetlerin başında Bakara sûresi gelmektedir. Bakara sûresinde tahrîf kelimesi sadece bir âyette geçmektedir. ${ }^{46}$

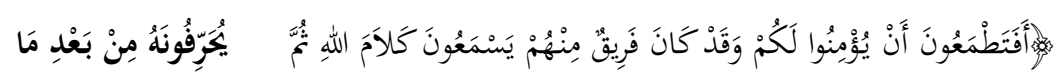

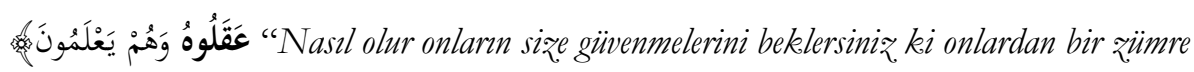
vard ki Allah'in kelamm isitip akıllart aldıktan sonra, bile bile onu tahrîf eder, değiştiritlerdi'. ${ }^{47}$

\footnotetext{
Elmalıl, Hak Dini Kur'ân Dili, I, 327; III, 246.

40 Taberî, Câmiü'l-beyân II, 248;İbn Atıye, el-Muharraru'l-vecî̌z I, 166.

1 Bkz. Gaudeul-Caspar, "Kitab-1 Mukaddes'in Tahrîfi.....” s. 157, 158.

İbn Teymiyye, Cevâbü's-sahîh, Dârü'l-Âsıme, 1994, I, 367.

Râzî, Mefâtîhû̀'l-ğayb, III, 560.

44 Elmall1, Hak Dinî Kur'ân Dili, I, 326, 327.

45 Ateş, Süleyman, Yüce Kur'ân'ın Cağdaș Tefsîri, Yeni Ufuklar Neşriyat, İstanbul t.s. I, 185, 186.

46 Bakara 2/75.

47 Bakara 2/75. Mukayesi için bkz. KM, Yaremya, 8/8; 2/22-24.
} 
Taberî bu âyeti yorumlarken önce tahrîfin nasıl olduğu konusunda tefsîrde ihtilâfların olduğunu, Mücâhid ve Ebû Nüceyh'in tahrîfi "bazı hükümlerin gizlenmesi”; İbn Zeyd'den "dünyevî menfaat karşılığında helalin haram, haramın da helal, hakkın batıl, batılın da hak gösterilmesi” görüşlerini nakletmiştir. ${ }^{48}$ Kendisi de âyette geçen tahrîf kelimesinin manâ/yorum anlamında olduğunu beyan etmiştir. Bunları yapanların da İsrailoğullarının hepsi olmayıp sadece onlardan bir guruptur. ${ }^{49}$ Zemahşerî âyetin açıklamasında lafzî ve manevî ayrımına girmez. Ancak o, Yahûdîlerin Hz. Peygamberin sıfatlarını gizlemesi ve kavimlerinden ileri gelenlere recm cezasını vermemeleri dolayısıyla daha çok manevî olduğuna vurgu yapar. ${ }^{50}$ Endülüs müfessirlerinden İbn Atıyye'nin (ö. 546/1151) de tahrîfi manâ bağlamında yani Taberî gibi açıkladığ1 görülür. ${ }^{51}$ İbn Atıyye tahrîfi İbn Abbâs'n böyle tevil ettiğini ve bazı müfessirlerin de bu görüşü kabul ettiğini aktarır. ${ }^{52}$ Râzî’nin Tevrât'ın tahrîfi konusundaki ağırlıkl görüşü bu âyet için lafzen olduğudur..$^{53}$ Râzî̀ye göre, âyete hemze-i istifhamla başlanılması Hz. Peygamber dönemi Yahûdîlerinin imana gelmeyeceklerine işarettir. Çünkü onların ataları da Hz. Mûsâ gibi ülü’l-azm bir peygamberi ve mucizelerini gördükleri halde ona inanmamışlar ya da Samirî olayındaki gibi kısa bir süre zarfında tekrar eski inançlarına geri dönmüşlerdir. Dolayisiyla onlardan iman beklenilmemelidir. ${ }^{54}$

Elmalılı'ya göre; bir grup vardır ki, Allah'ın kelamını yani Tevrât'ı işitirler, bellerlerdi de sonra onu bile bile tahrîf ederler, anlamını değiştirecek bir surette kelimelerin ve harflerin yerlerini, manâlarını değiștirirlerdi. Hem bunu anlayamadıklarından, akıl ve idrak noksanlığından değil, akılları ererek, ne manâsından ne de Allah kelamı olduğundan asla şüpheleri olmadan bile bile ve kasten yaparlardı. Elmalılı âyetin siyâk ve sibâkına da riâyet ederek, Kur'an'ın asıl Tevrât'1 tasdik eden beyanları ve İsrailoğulları hakkında gizli bilgilerden müslümanların haberdar olduklarını, Hz. Peygamber'in vasıf ve özelliklerinin Tevrât'ta anlatıldığını bildiklerini, Allah'ın kendi peygamberine bunları bizzat vahy yoluyla bildirdiğini nakleder. O Yahûdî bilginler bunları bildikleri halde, bildiklerini söylememek ve yeri geldikçe onları tahrîf etmek onların şiarı olduğundan bunları gizlerler. ${ }^{55}$ Dolayisiyla Tevrât'ta hangi konularda tahrîf yapıldığını bilmemizin sebebi de, tahriffi yapılan konuların vahy yoluyla $\mathrm{Hz}$.

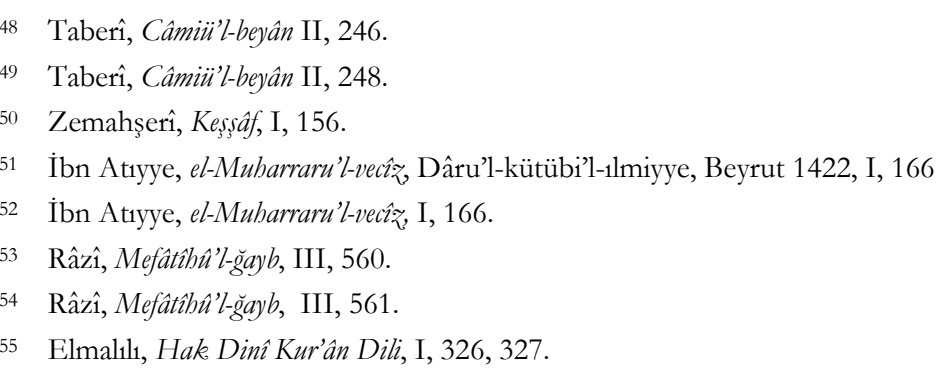


Peygamber'e bildirilmesidir. Elmalılı'nın yorumundan anlaşıldığına göre bu âyette Yahûdîlerden bir grup kastedilmiştir ve tahrîf Tevrât'in lafzen ve manen değiştirilmesi şeklinde vuku bulmuştur. Elmalılı'nın açıklamalarına dayanarak bu gurubun Yahûdî alimleri olduğunu anlayabiliriz. Genelde incelediğimiz her müfessir tahrîfin Yahûdîlerden alim bir grup tarafindan yapıldığını söylemektedirler. Bize göre bunlar böyle bir kanıya, başka müfessirlerden etkilenerek varıyor olabilirler. Ayrıca bu müfessirlerin verdikleri bilgiler doğrultusunda aynı dönemde yaşamış olanların kendi aralarında da bir ilişkinin varllğından söz etmemiz mümkün görünmektedir.

Vehbi Efendi, (ö. 1949) bu âyetin tefsîrinde tahrîfi ahkâma has kılmaktadır. Yahûdîlerin Hz. Mûsầya iman etmelerinden sonra Hz. Mûsâ’nın aralarından ayrılmasıyla hemen Samirînin yaptı̆̆ı buzağı suretine ibadet etmelerini ve istiğfar etmeleri için emredilen kelimeyi değiştirmelerini örnek olarak göstererek, onların tahrîfi nasıl yaptıklarını da açıklamaktadır. ${ }^{56}$ Vehbi Efendi’nin âyete verdiği manâya bakıldığında ise tahrîfi önce "tağyîr" sonra da "ahkamını tebdîl" şeklinde tercüme ettiği görülür. Bu açıklamayla onun yorumsal tahrîfin yanında metinsel/lafzî tahrîfi de kabul ettiği anlaşılmaktadır. ${ }^{57}$

Bilmen (ö. 1971) ise bu âyetin tefsîrini Allah'in Kelam'ı olan Tevrât'1 işitirler, dinlerler, içeriğini anlarlar fakat sonra onu tağyîre çalışırlar. Onlar Tevrât'ta Hz. Peygamber'in vasıflarını görüp okurlar da bunu örtbas ederler, tebdîle cüret gösterirler şeklinde yorumlamıştır. ${ }^{58}$ Tahrifin ne şekilde vuku bulduğu konusunda açık bir ifade bulunmamakla birlikte Bilmen'in "başkaları buna vâkıf olarak İslamiyet'i kabul etmesin diye tebdîle cüret gösterirler" ifadesinden Kitap'ta, değişiklik yaptıklarını anlıyoruz. Bu değişikliğin lafızda mı yoksa anlamda mı olduğu tam olarak anlaşılamamaktadır. Bilmen, âyette geçen tahrîfin diğer bir yorumunun da Yahûdîlerden yetmişe yakın zatın Sinâ Dağı'nda Hz. Mûsầnın Yüce Allah'la olan konuşmasını işittikten sonra bu ilahî kelamın mealine muhalif iddialarda bulunmaları olduğunu belirtmiştir. ${ }^{59} \mathrm{Bu}$ yorum, çok ilginç olmakla beraber genelde kabul gören bir görüş değildir. Zaten Bilmen'in de bu görüşü kendine ait olarak değil, böyle bir yorumun da olduğuna işaret etmek için verdiği görülmektedir. Bu görüşü nerden aldığına dair herhangi bir bilgi verilmemekle birlikte böyle bir yorum da mümkün olabilir. Çünkü sonuçta bahsedilen durumda da vahy söz konusudur ve bu vahyi değiştirmeleri de Allah'ın kelamında yaptıkları bir tahrîftir. Ancak Kur'ân ve tefsîrlerden bildiğimiz kadarıyla, Hz. Mûsâ yetmişe yakın kişiyle önceden Sinâ dağına gidiyor, sonra da o yetmiş kişiyi geride bırakıp Allah’la konuşuyor, kendisine ilk

56 Vehbî Efendi, Hulâsatül-beyân, Üçdal Neşriyât, İstanbul 1966, I, 156.

57 Vehbî Efendi, Hulâsatü'l-beyân, I, 156.

58 Ö. Nasuhi Bilmen, Kur'ân-ı Kerîm”in Türkçe Meali Âlisi ve Tefsiri, Bilmen Yay., İstanbul, I, 73

59 Bilmen, Meali Ali, I. 73. 
söylenen kavmini arkada bırakıp niçin erkenden geldiği sorusudur, sonra da Yüce Allah, ona kavminin Samirî tarafindan saptırıldığını bildirmektedir. Yalnız buradaki kavim yetmiş kişiye değil arkada kalan İsrailoğullarına işaret etmektedir. Bu nedenle yetmiş kişi aslında Hz. Mûsâ'nın Allah'la konuşmaya giderken seçtiği şanslı insan grubudur. Özetle onların tahrîfatta bulunması tefsîri malzemeye göre biraz muhal gibi görülmektedir.

Çağdaş müfessirlerden Süleyman Ateş'e göre ise, Kur'ân'da bahsedilen tahrîf, metnin değil, yorumun değiștirilmesidir. "Allah'ın sözlerini ișitirler, sonra da onu anladiktan sonra tahrîf ederler" denilmesi, Yahûdîler'in, var olan Allah kelamını duyduklarını, hatta bu kelamın amacını anladıklarını; fakat daha sonra çıkarları için yanlış yorumlar yaptıklarını ifade etmektedir. ${ }^{60}$ Süleyman Ateş, "Sizin yanınızda bulunanı doğrulayıcı olarak indirdiğimiz bu Kur'ân’a inanın..." şeklindeki âyetten hareketle, Hz. Peygamber döneminde Yahûdîlerin ellerinde bulunan Tevrât'in muharref olmadığı, ilâhî bir kitap olduğu sonucuna ulaşmaktadır. Eğer Tevrât o dönemde tahrîf edilmiş olsaydı, Kur'ân'ın bu kitabı tasdik etmesi söz konusu olamazdı. Ateş'e göre, Tevrât'taki tahrîf, Hz. Peygamber döneminden sonra meydana gelmiştir; bunun delili, Kur'ân'da İsrailoğulları ile ilgili anlatılan bazı olayların, mevcut Tevrât'ta bulunmamasıdır. ${ }^{61}$ Ancak görebildiğimiz kadarıyla Süleyman Ateş, Kur'ân'da anlatılıp da Tevrât'ta bulunmayan bu olayların hangileri olduğunu açılamamaktadır. Süleyman Ateş'e göre, Hz. Peygamber dönemindeki Yahûdîler, kendi kutsal kitaplarında Hz. Muhammed'in peygamberliğine işaret eden bazı cümleleri saklamışlardı; ${ }^{2}$ daha sonra saklanan bu parçalar kaybolmuştur; zira o dönemde elle yazılan Kutsal Kitap nüshaları çok fazla değildi. Herhangi bir nüshadan bazı parçaların saklanması, o nüshanın, eksik bir şekilde yayılmasına neden olmuştur. Nitekim Yahûdî Kutsal Kitabi Tanah'ta Süleyman'mn Taribi gibi kitaplardan bahsedilmektedir; ${ }^{63}$ ancak bu kitaplar mevcut Tevrât'ta bulunmamaktadır. ${ }^{64}$ Ateş'in başka bir iddiasına göre ise, Kur'ân'ın Tevrât'ı tasdik etmesi, Tevrât'in Hak Kitap olarak kabul edilmesi anlamına gelir. Ancak bu bizi, Tevrât'a insan elinin değmediği sonucuna ulaştırmaz. Kur'ân, Tevrât'ın genel prensiplerini ve yasalarını tasdik etmektedir. Süleyman Ateş’in konuyla ilgili görüşlerini açıkladığı yazısında dikkati çeken bir diğer husus, asıl Tevrât'ın, Kutsal Kitab'ın

60 Ateş, Yüce Kur'ân'in Çăgdaş Tefsîri, s. I, 185, 186.

61 Ateş, Yüce Kur'ân'ın Cağdaș Tefsiri, II, 297-298; Kur'an-ı Kerim'in Evrensel Mesajına Cağr, Birleşik Yay., İstanbul 1990, s. 136-137; “Cennet Tekelcisi mi?”, İslâmî Araştırmalar, c. 4, sy. 1, Ocak 1990, s. 33-34; “Tahrîf”, Kur'ân Ansiklopedisi, Kur'ân Bilimleri Araştırma Vakfi, İstanbul 1997, XIX, 465.

62 Bkz. Mâide, 5/15.

63 Yeşu, 10:13; I. Krallar, 11:41. Benzer kullanımlar için bkz. I. Krallar, 14:19, 29; 15:7, 23, 31.

64 Ateş, Yüce Kur'ân'ın Çăgdaş Tefsiri, II,495-496. 
başlangıcındaki ilk dört kitap olduğunu belirtmesidir. ${ }^{65}$ Ateş’in, genel kabulün aksine, Tevrât'1 beş kitap değil de dört kitap olarak görmesinin nedeni anlaşılamamaktadır. Diyanet Kur'ân Yolu tefsîrinde ise tahrifin hem lafızda hem de manâda olduğu ifade edilmektedir. ${ }^{66}$

\section{Nisâ Sûresi 4/46. Âyeti Etrafinda Yapılan Yorumlar}

Nisâ sûresinde de Yahûdîlerin inançlarındaki bozukluklara değinildiği için doğal olarak bunun şekline de değinilmiştir. Bu konu ile alakalı bir âyette şöyle buyrulur:

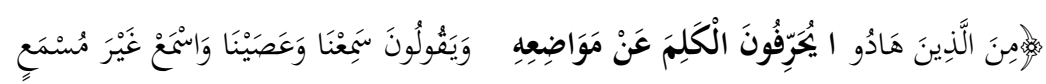

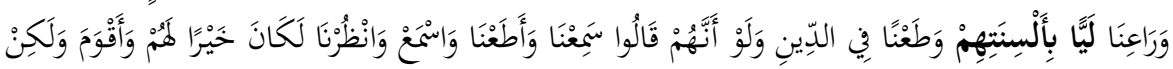

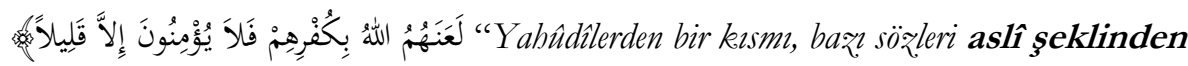
ve manâsından saptır1r, mesela: "İsittik" (ama isyan ettik), "işit" (hay işitmez. olası!), ve râina derler. Bu sö̊leri, ağ1zlarını ĕ̈ip bükerek güya vaziyeti kurtarmak ve dinle alay etmek için söylerler. Halbuki onlar sadece "İsittik ve itaat ettik", "Sende bizi işit!" انْظُرْنَ / unzurnâ (bizi de gözet!), deselerdi kendileri için elbette daha hayurl ve daha dürüst bir is olurdu. Fakat Allah, inkârlar yüzünden onlar rabmetinden kovdu. Artık onlar pek az. iman ederler". 67

Mâtürîdî, âyette geçen "kelimenin tahrîfi" ibaresinin iki anlama gelebileceğini, bunlardan birincisinin lafiz yoluyla ikincisinin de manâ yoluyla gerçekleşeceğini söylemekte ve bunun batıl veya fasit te’vîllerle olduğunu ifâde

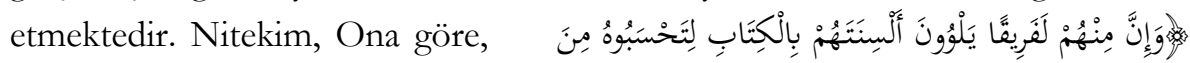

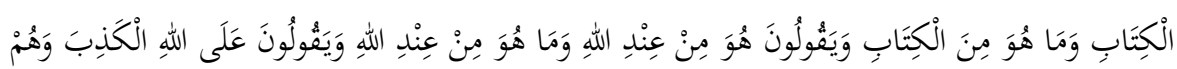
يَعْلَمُونَ "Ehl-i kitaptan bir kism da, aslinda kitaptan olmadiğ halde, sizin kitaptan zannetmeniz için, Okurken ağızlarm dillerini eğ̈p bükerler. Bir seyler söyleyip "Bu Allah tarafindandir" derler. Halbuki o, Allab tarafindan değildir. Bile bile Allah adina yalan uydururlar" ${ }^{68}$ âyeti buna delil teşkil eder. ${ }^{69}$ Lafzın değiştirilmesiyle alakalı olarak

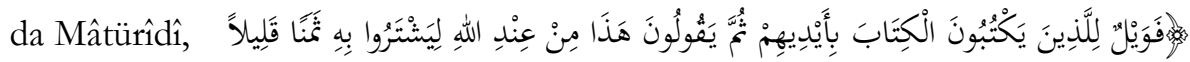

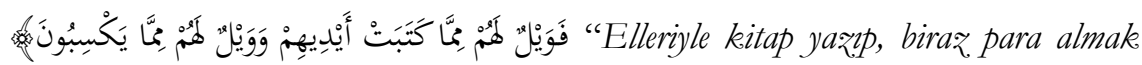

65 Ateş, Kur'an-ı Kerim'in Evrensel Mesajina Çă̆rı, s. 138-139.

66 Karaman ve dğr., Kur'ân Yolu, I, 146.

67 Nisâ $4 / 46$.

68 Âl-i İmrân 3/78.

69 Mâtüridî, Te'vîlâtü ebli's-sünne, I, 285. 
için: "Bu Allah tarafindander" diyenlerin vay haline! Vay o ellerinin yazdlklarndan ötürü onlara! Vay o kazandıklar vebal yü̈zünden onlara!'70 âyetini delil göstermiştir.

Söz konusu âyetleri tefsîr ederken Zemahşerî, te'vîl yoluyla inhirâflara ve tahrîflere girmenin mümkün olacağını ifâde etmiştir. ${ }^{71}$ Ancak Zemahşerî’nin ağ عَنْ مَوَاضِعِِِ ifadesi ile bir başka âyette geçen مِنْ بَعْدِ مَوَاضِعِِ ifadesi de oldukça manidardır. Çünkü her ikisinin ifade ettiği anlam birbirinden farklıdır عَنْ مَوَاضِ mânen; diğeri olan مِنْ بَعْدِ مَوَاضِعِِِ de konulduktan sonra yani lafzendir. ${ }^{72}$

İbn Attyye tahrîf konusunda iki görüş olduğunu söyler. Bu görüşlerden ilki tahrîfin lafizda olması diğeri de tevîlde/yorumda meydana gelmesidir. ${ }^{73}$ Râzî de bir kutsal metnin tahrîfinin lafiz, manâ ve değişik şekillerde olabileceğini ifâde eder, İslâmda da, manâ yani te'vîl yoluyla ehl-i bid'a mezheplerinin bazı âyetleri inançlarıyla uyuşmadığı için farklı şekillerde yorumlamalarının da bu kapsama dahil olduğunu belirtir. ${ }^{74}$ Râzî, bu âyet için manevî tahrîfi savunmaktadır. Diğer yandan Râzî̀ye göre âyette kavim lafzının mukadder olduğunu ve bu âyette sözü edilen kimselerin Yahûdîlerden olduğunu ileri sürmüştür. Fakat sözü edilen bu kavimle ilgili bir açıklama yapmamıştır. ${ }^{75}$

Elmalılı da, Râzî gibi âyette kavim lafzının mukadder olduğunu ve sözü edilen kimselerin Yahûdîlerden bir kavim olduğunu söyler ancak herhangi bir isim belirtmez. ${ }^{76}$ Ona göre, söz konusu kimselerin Yahûdîler olduğu konusunda şüphe yoktur. Çünkü Yahûdîler kelimeleri yerlerinden kaldırıp değiştirmişler, dillerini de eğip bükmüşlerdir. Elmalılı, tahrîfin şekilleri hakkındaki görüşlerini üç şekilde bildirir: İlk olarak bir kelimeyi diğer kelime ile değiştirirler ki bu yazıdaki değiştirmedir. İkincisi, ortaya şüphe atma ve yanlış yorumlarla bir kelimeyi öteye beriye çekerek manâsını haktan batıla çevirmektir ki, bu da tefsîr ve açıklamada yapılan bir manevî tahrîftir. Son olarak ise yalnız kitapta değişiklik yapmaları değil, bir söz söyledikleri zaman duydukları ve bildikleri gibi dosdoğru söylemeyip değiştirerek söylemeleridir. Çünkü Yahûdîler Hz. Peygamber’in huzuruna gelirler, bazı şeyler sorarlar, yanından çıttıkları zaman sözlerini

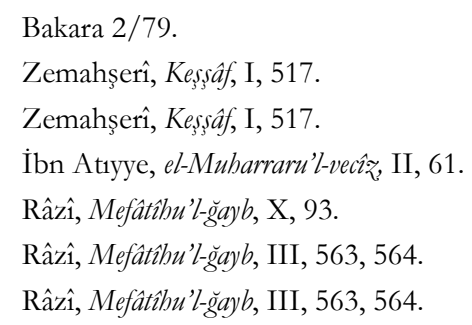


değiştirerek yaymaya çalışırlardı. ${ }^{77} \mathrm{Bu}$ nokta ilginçtir, çünkü burada tahrîf kelimesinin semantik alanı genişletilmektedir. Bu yoruma göre tahrîf, sadece ilahi metinler için kullanılan teknik bir terim olmayıp, insanların günlük tavır ve konuşmalarındaki değişikliğe de işaret etmektedir.

Vehbi Efendi’ye göre tahrîf; bir kelimenin makamına diğer bir kelime yazılmak suretiyle olduğu gibi yorumunun bozuk yapılmasıyla yani manâsını tağyir etmekle de olur. Asr-1 saadet döneminde; Hz. Peygamber’in huzuruna bir şey sormak için gelen Yahûdîlerin, aldıkları cevabı Hz. Peygamber'in huzurundan çıarken değiştirmelerinin çok kere vaki olduğunu örnek vererek bu fikrini destekler. Yine onun da Elmalılı gibi bu konuda Râzî̀yi referans aldığı görülmektedir. ${ }^{78}$ Kavimden neyin kastedildiğini kesin olarak anlayamamakla birlikte Vehbi Efendi, Tevrât'ın kelimelerini mahallinden çıkarmak ve manâsını değiştirmekle tahrîfi Yahûdî ulemasının gerçekleştirdiğini belirtir. Vehbi Efendi’nin tahrîfatla uğraşanların tahrîfatı daraltmakta oldukları görüşünü buradan çıkarabiliriz. Sanki o bu sözüyle tahrîfin belli konularla sınırlı olduğunu ve bu kitapların bir hayli hakikat içermesini de ima etmektedir. Ayrıca Vehbi Efendi'nin bu âyetteki yorumundan, tahrîfin lafzen ve mânen yapıldı̆̆ı sonucunu da çıkarabiliriz.

Bilmen, âyetlerde geçen 'kelimelerin yerlerini tahriff ederler' ifadesini âyetlerin hilafını söylemeleri, o kelimelerin yerlerine başka kelimeleri yerleştirmeleri veya o kelimeleri muradı ilâhiyeye muhalif, fasit bir şekilde tevîl etmeleri şeklinde açılar. ${ }^{79}$ Bilmen'in bu açılamasından tahrîfin lafzen ve manen yapılmış olduğu anlaşılmaktadır. Âyette geçen gurup hakkında ise Bilmen; "o düșmanlar", "o dalaleti satın alanlar", "o müslümanları doğru yoldan saptırmak isteyenler" şeklinde açıklama yapmakla yetinmiştir. $\mathrm{O}$, tahrîfatı biraz daha genelleştirmiş, -bu işleri yapan- her Yahûdîyi potansiyel olarak bu grubun içine dahil etmiştir. Ancak Bilmen'in, açıklamalarına genel olarak bakıldığında yorumda tahrîfe çok fazla vurgu yaptı̆̆ görülmektedir.

Bizce tahrîfin nasıl olduğu yine aynı âyette doğrudan kutsal kitabın tahrîfine değil de Yahûdîlerin kutsal kitap ve din karşısındaki tavırlarına işaret edilmiştir. Dolayısıyla burada tahrîfin şekli ile ilgili yaklaşımlardan ve Tevrât'tan ziyade onun muhataplarının karakterinin anlaşılması ve tahrîfin eş anlamlılarından olan "leyy" kelimesinin kullanılması, aynı zamanda sözlü bir ifadenin lafzen ve manen nasıl değiştirildiğini açıklamaktadır. Dolayısıyla "leyy" kelimesi tahrîfle yakın anlamada kullanılsa da aslında onun bir şekli olarak anlaşılmalıdır.

77 Elmallı, Hak Dini Kur'ân Dili, II, 566, 567.

78 Karşılaştırınız. Râzî̀, Mefâtîhu'l-ğayb, , III, 563, 564; Vehbî Efendi, Hulâsatü'l-beyân, ÜI, 938.

79 Bilmen, Meali Âli, II, 599. 


\section{Mâide 5/13. Âyeti Etrafında Yapılan Yorumlar}

Mâide sûresi 5/13. âyetinde tahrîfle ilgili olarak şöyle buyrulmaktadır:

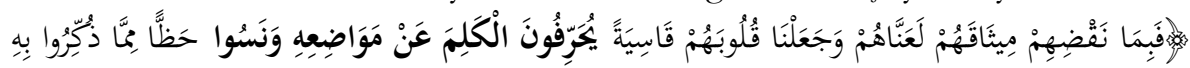
o Yabûdîleri, verdikleri kesin sözü bozduklarndander ki lânetledik, onlarn kalplerini katılastırdı. Böylece onlar kelimeleri yerlerinden oynatarak tahrîf ederler. Kendilerine tebliğ edilen hususlardan pek çoğunu unuttular. Onlarm pek ą̧ haric olmak üzere, onlar tarafindan devamle olarak hainlik görürsün. Yine de sen onlar affet, aldrrma! Cünkë̈ Allah iyilik edenleri sever". ${ }^{80}$

Taberî, âyette geçen "kelimelerin yerlerini oynatarak tahrîf etme" ifadesini İbranîcede "rînâ, abdün, keramün" gibi kelimelerin Arapçaya yakın telaffuzları dolayısıyla ya da Arapçada farklı manâya gelmesi olarak açıklar. ${ }^{81}$ Râzî, tahrîfi lafız ve manâ olarak kabul etmekle birlikte عَنْ مَوَاضِعِ "an mevâdı" ifadesine bakarak ilgili âyetin sadece manevî tahrîfattan bahsettiğini bildirmektedir. ${ }^{82}$ Elmalılı, bu âyette İsrailoğullarının vermiş oldukları sözü yerine getirmediklerinden ve bu yüzden de lanetlenmiş olduklarından bahseder. $\mathrm{O}$, "kelimeleri yerlerinden değiştirerek bozarlar" ibaresi için "kelimeyi şuraya buraya çekerek kelamı değiştirirler" anlamını verir ve şöyle devam eder: "Bu, onların öyle bir adeti olmuştur ki, Allah'ın kelamını ve arzularına uymayan ilahi hükümleri bozar ve değiştirirler. Nitekim onlar Tevrât'taki "recm" âyetini reisler hakkında "kömürle yüz karalamak" diye yorumlamaya kalkışmışlardı. Fırsat bulunca kelimeleri de değiştirirler, fakat çoğunlukla buna imkan bulamadıklarından dolayı bozgunculuklarını fâsit yorum yaparak gerçekleștirirler. Allah'ın kelamını bozmaktan daha büyük bir kalp katılığı düşünülemez". ${ }^{33}$ Elmalılı, bu açıklamadan anladığımıza göre Tevrât'ta tahrîfin daha çok yorumda yapıldığı görüşünü ileri sürmekte, Yahûdîlerin lafzen tahrîfe çok firsat bulamadıklarını ima etmektedir. Lafzen tahrîfin daha az olduğu görüşü, âyetin metninde geçen 'kelimeleri yerlerinden değiştirerek bozarlar' ibaresine uygun olduğu kanaatindeyiz. Çünkü bu ibarede manevî bir değişiklikten bahsedilmektedir. Genelde عَنْ مَوَاضِعِ "an mevâdı" ifadesi manevî tahrîf olarak yorumlanmaktadır. ${ }^{84}$ Lafzen tahrîfi kabul etse de Elmalilı, bugün

\footnotetext{
80 Mâide 5/13.

81 Taberî, Câmiü'l-beyân, II, 463. Bunun Yüce Allah'ın bazı isimlerine benzemesinden dolayı da nehyedildiği söylenmiştir. Bkz. Taberî, Câmiü'l-beyân , II, 463.

82 Râzî̀, Mefâtîhu'l-ğayb, XI, 324.

83 Elmalıl, Hak Dini Kur'ân Dili, III, 184.

84 Râzî̀, Mefâtîhu'l-ğayb, XI, 324.
} 
mevcut Tevrât'in tamamen bozulmuş bir kitap değil de içinde çok az lafzî değişikliklerin bulunduğu bir metin olduğunu ima etmektedir. Başka bir ifadeyle Tevrât lafız olarak Tanrı'nın İsrailoğullarına gönderdiği birçok hakikati içermektedir.

Vehbi Efendi, bu âyet için 'Beni İsrail, Tevrât'ta bahsedilen ahir zaman nebisine iman edeceklerine ahdetmişken onunla ilgili âyetlerin asıl manâlarını tağyîr ettiler, Tevrât'ta kendilerine zikrolunan nasibi terk ettiler ve emrolundukları şeyleri işlemediler" yorumunu yapmıştır. Âyette geçen kelimat-ı ilabiyyeyi mahallinden tağyâr sözüyle kastedilen; kelimeleri kaldırıp yerine başka kelime koymak ve kelime-i tevhidi değiştirmeksizin fâsid yorumlarla tevîl etmektir. Çünkü Yahûdîlerde bu hallerin hepsinin vaki olduğunu Yüce Allah, Kur'an'ın çeşitli yerlerinde bildirmiştir. ${ }^{85}$ Kitaplarında emrolundukları hüküm, Resûlullah'a iman edip, dinine yardım etmekti. Fakat Resûlullah zuhur edince işlerine gelmediğinden Tevrât'ın ahkamını unutuverdiler. Ayrıca Yahûdîlerin İslam dinine arkası kesilmeksizin hiyanet ettiklerine ve bu durumun

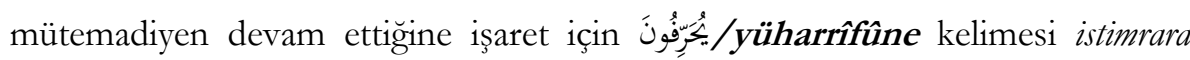
delalet eden muzari sigası ile zikredilmiştir. ${ }^{86}$ Vehbî Efendi, bu âyette de, Yahûdîlerin tahrîfi lafzen yaptığına dair bir işaret bulunmadığını, tahrîfi manen yapıldığını savunmaktadır. Bu âyet, Beni İsrail'in ahdlerine riayet etmeyip, devamlı haince hareketlerde bulunup durduklarını bildirmektedir. Şöyle ki: Beni İsrail, ahd ve misakta bulunmuşlardı, buna riayet etmediler, sonra ahidlerinin tersine hareket etmeleri sebebiyle lanete uğradilar, Yüce Allah'in rahmetinden uzaklaştırıldılar ve kalpleri kaskatı yapıldı ve böylece imanı kabule müsait olmayan bir kasvete tutulmuş oldular. Onlar kelimeleri Yüce Allah'ın tertip buyurmuş olduğu yerlerinden tağyîr ederler, yani $\mathrm{Hz}$. Peygamber'in vasıflarıyla ilgili âyetleri tebdîl ve tahrîfte bulunurlar. ${ }^{87}$ Bilmen ise, bu âyetin açıklamasında da tahrîfi Yahûdîlere has kılmıştır. Hıristiyanlarla ilgili herhangi bir açıklamada bulunmamıștır. Burada Bilmen, tahrîfi manâ ve lafız olmak üzere her ikisini de kabul etmesine rağmen ağırlıklı olarak manâ yönü üzerinde durmuştur. Reşid Rıza ise, mezkûr âyette geçen "kelimelerin mevzilerinden tahrîf edilmesi" ifadesini, takdim-tehir, ekleme ve çıkarma yapmak ya da yanlış anlam vermek şeklinde açıklamaktadır. Ona göre, Tevrât ve İncîller hem manâ hem de metin olarak tahrîf edilmiştir. ${ }^{88}$

Tefsîrlere bakıldığında müfessirler diğer âyetler gibi bu âyeti de bazı tarihi hâdiseler ve Medine Yahûdîlerinin etkisi altında kalarak açiklar. Âyetin

\footnotetext{
85 Vehbî Efendi, Hulâsatü'l-beyân, III, 1174, 1175.

86 Vehbî Efendi, Hulâsatü'l-beyân, III, 1174, 1175.

${ }^{87}$ Bilmen, Meali Âli, II, 740.

${ }^{88}$ Reşid Rızâ, Tefsîru'l-menâr, V, 140.
} 
anlamı yine kendi içerisinde başka bir kelime ile açılanmaktadır. O da "nisyân/unutma" kelimesidir. Demek ki Tevrât'ın muhatapları tarihi süreç içerisinde kitaplarından bazı yerleri isteyerek veya istemeyerek unutmuşlar, bunun sonucunda da kitaplarında tahrîf meydana gelmiştir.

\section{Mâide 5/41. Âyeti Etrafinda Yapılan Yorumlar}

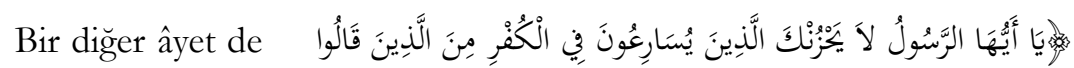

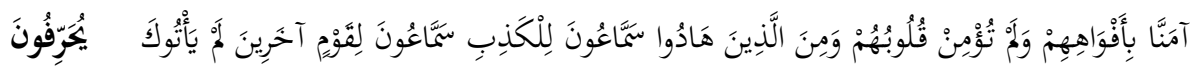

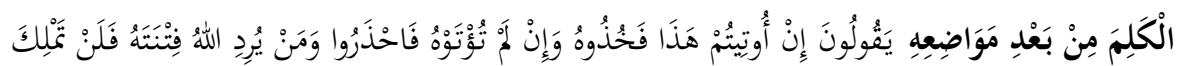

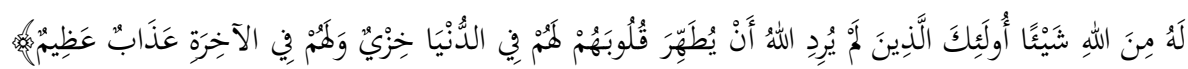
"Ey Peygamber! Kalpleri iman etmediür balde ağrzlaryla "iman ettik" diyen münafiklarla, Yabûdîlerden kâfirlikte yarısanlar seni üzmesin. Zira onlar yalancllk etmek için dinlerler. Senin yaninda olmayan bir grup hesabma casusluk için dinlerler. Kelimeleri konuldukları yerlerden çıkarıp tahrîf ederler. "Size şu fetva verilirse onu kabul edin, o verilmease kabul etmekten geri durun" derler. Allab birini șassitmak isterse, sen onun lebinde Allab'a karşı biçbir șey yapamazsın. Onlar öyle kimselerdir ki Allah onlarn kalplerini arnndrmak istememiștir. Onlarn bakkı dünyada rüsvayllk olduğu gibi, âhirette de müthis bir cezader". ${ }^{89}$

Bu âyet Yahûdîlerden evli bir erkekle kadının zina etmesi sonucu nazil olmuştur. Tevrât'ta hükmü recm olan bu cezanın İslâm'a göre hafifleyeceğini umarak Hz. Peygamber'e gelmişlerdir. Lakin araştırma sonucu Hz. Peygamber recme karar verince onlar bunu değiştirip sopa vurulup sonra yüzlerine kara çalınıp sokak sokak dolaştırlır demişlerdir..$^{90}$ Taberî̀ye göre; Yüce Allah Tevrât'ta farzını farz, helalini helal, haramını haram kilıp her biriyle alakalı âyetleri yerine koyarak Yahûdîlere amel etmelerini emrettiği halde Yahûdîlerin ilahi emirlere razı olmayarak tahrîf ve tağyîrde bulunduklarını Yüce Allah, bu âyetle açıklamıştır. Mesela Tevrât'ta zina cezası recm iken eşraf için recmi değneğe ve yüzünü karalayıp eşeğe ters bindirmeye tebdîl ettiler ve Resûlullah'a bu konuda soru sormaya gelenlere; Resûlullah arzularına muvafik cevap verirse kabul etmelerini, arzularının aksine cevap verirse kabul etmemelerini tenbih ettiler. ${ }^{91}$ Hâzin'in de Taberî ile aynı görüşü paylaşttğ1 görülür. ${ }^{92}$ Râzî̀ye göre buradaki tahrîf lafzî tahrîftir. Çünkü "min ba'di mevâdı" ifadesi kelimeler yerine

89 Mâide 5/41. Karşılaştırma için bkz. KM, İşaya 29/13; Matta 15, 8; Markos 7,6.

90 Ebû Dâvûd, “Hudûd” 26. Sünen, el-Mektebetü'l-İslâmiyye, İstanbul ts.

91 Taberî, Câmiü'l-beyân, X, 310, 311.

92 Bkz. Taberî, Câmiü'l-beyân, X, 310; Hâzin, Lübâbü't-te'vîl, Dâru'l-kütübi'l-1lmiyye, Beyrut 1415, II, 42, 45 . 
konulduktan sonra anlamına gelir. ${ }^{93}$ Çünkü onlar nüzul sebebi ve ilgili âyette ifade edildiği "recm" kelimesi yerine "celd" kelimesini koymuşlardır.94 İbn Atıyye de bu âyetteki tahrîfi açıklarken doğru lafız varken yalan olarak söylemelerini ve kitaba göre hüküm vermemeleri yorumunu yapar. ${ }^{95}$ Vehbi Efendi’nin bu konuda tamamen Taberî̀den etkilendiği ve onunla aynı görüşü paylaştığ1 görülmektedir. ${ }^{96} \mathrm{Bu}$ âyetin sebebi nüzûlü konusunda Elmalıll, Bilmen'in aynı âyet üzerindeki açıklamasında gördüğümüz rivayeti zikreder. Ancak Elmalılı bu rivayeti nereden aldığı konusunda bizi șüphede bırakmaz. Elmalıı'nın bu rivayetleri sahabeye dayandırmasından anlıyoruz ki Tevrât'ta bahsi geçen bu konular, hadîslerde de yer almaktadır. ${ }^{97}$ Zira Vehbi Efendi ve Bilmen'in bu bilgiyi bizzat Tevrât'tan $\mathrm{m} 1$ yoksa başka kaynaklardan $\mathrm{m}$ aldıkları kapalı kalmıştır.

Elmalılı, bahsi geçen Yahûdîleri Ehl-i kitap değil bilakis kafir kabul etmekte, bu da ilgili âyetle çelişmemektedir. Bu yorumunu da o, Kur'ân'la desteklemektedir.

Yahûdîlerden bir grubun Hz. Peygamber'in huzuruna gelip O'nu hakem tayin etmek istemelerinin de arka planını ele alan Elmalıli; onların hakeme başvurmaları fikrinin doğruluktan ve iyi niyetten kaynaklanmadığını sadece arzularına bir çare aramak maksadıyla bu yola başvurduklarına dikkat çeker. Elmalılı, sonraki âyetlerin de 1şı̆̆ında bu konuyu şu şekilde değerlendirir: Yanlarında Tevrât varken onlar neden Hz. Peygamber'i hakem tayin ediyorlar? Hiç şüphe yok ki, Allah'in hükmüne ve kendilerinin iman ettiklerini iddia ettikleri Kitab'a imanları yok da ondan. O halde bunlar asla mü'min değillerdir. Ne Tevrât'a iman ederler, ne Kur'an'a; ancak arzularının arkasında koşarlar. Âyetlerin devamında Yahûdî bilginlerden de bahsedilir ve peygamberler gibi onların da görevlerinin Allah'ın kitabında olanı korumak olduğu açıklanır. Sonuçta da kim Allah'n indirdiği kitap ile hükmetmez, onun hakimiyetini tanımazsa işte bunlar kafirlerdir, buyrulur. Elmalıll, bu kafirler için "elem verici, devamlı azap vardır ve bunlar ateşten çıkmak isteseler de çıkamazlar" şeklinde yorumda da bulunur. ${ }^{98}$

Bilmen, bu âyetin sebeb-i nüzulü konusunda șu rivayeti zikreder: Yahûdîlerin eşrafindan bir erkek ile bir kadın evli oldukları halde zina suçunu işlemişlerdi. Bunların durumu hakkında Tevrât'a göre recm cezası gerekiyordu.

93 Râzî, Mefâtîhu'l-ğayb, XI, 358.

94 Râzî, Mefâtîhu'l-ğayb, XI, 358.

95 İbn Attyye, el-Muharraru'l-vecîz, II, 192.

96 Vehbi Efendi, Hulâsatii'l-beyân, III, 1223, 1224.

97 Elmalılı, Hak Dini Kur'ân Dili, III, 242, 246.

98 Elmalılı, Hak Dini Kur'ân Dili, III, 248, 249. 
Bu cezadan kurtulmak için Hz. Peygamber'e müracaat etmeleri tavsiye olunmuş ve denilmiş ki: Gidin O'na müracaat edin. Eğer hafif bir ceza tayin ederse kabul edin, recm cezasına lüzum görürse kabul etmeyin. O grup Hz. Peygamber'e müracaat ettiğinde $\mathrm{Hz}$. Peygamber onlara verdiği hükme razı olup olmayacaklarını sormuş onlar da razı olacaklarını söylemişlerdi. Bunun üzerine Cebrail (a.s.) recm âyetini getirmiştir. Hz. Peygamber de recm gerektiğini onlara bildirmiştir, zaten onların büyük alimlerinden 'İbn Surya' da Tevrât'a göre recmin gerektiğini itiraf etmişti. Fakat onlar buna rağmen bu hükmü kabul etmemişler bunun tersine bir hükümde bulunulmasını arzu etmişlerdir. İște bu minval üzere; âyet bir takım İslam düşmanlarının yalancılıklarını ve hakikatleri tebdîl ve tağyîre çalışmalarını bildirmek üzere nazil olmuştur. ${ }^{99}$

Bilmen'e göre âyetin ilk kısmında sözü geçen grup münafiklardır. Daha sonra ise âyette Yahûdîlerden bahsedilmektedir ki bu iki topluluk, ilahi din aleyhindeki uydurma sözlere kıymet verirler, onları dinler dururlar. Kibirlerinden ve adavetlerinden dolayı Hz. Peygamber'e gelmeyen diğer bir kavmin de hakikate uymayan sözlerini ziyadesiyle dinleyicidirler, dini ahkam aleyhindeki sözlere kulak verirler, ondan zevk alırlar. Bu geride kalanlar kelimeleri yani ilahi kitaplardaki âyetleri, dini ahkamı, Yüce Allah tarafindan yerlerine konulduktan sonra lafzen veya manen tebdîl ederler, meşru olan bir şeyi gayr-i meşru, gayr-i meşru olan bir şeyi de meşru gibi göstermek isterler ve kendilerine tabi olanlara: "Eğer size Peygamber tarafindan bu, (kendilerinin tebdîl ve tahrîf ettikleri şey) verilirse alıveriniz, onunla amel ediniz; eğer bu (tebdîl edilen şey) verilmez, başkası tebliğ edilirse onu asla kabul etmeyiniz" derler. İşte bunlar hakikatleri tağyîre çalışan sapık kimselerdir. Onlar Allah'ın dinî ahkamını tahrîfe çalışan o kimselerdir ki, Yüce Allah, onların kalplerini dalaletten, küfür ve nifaktan temizlemeyi murad etmemiştir. Çünkü onlar o küfür ve nifakı kendi istekleriyle seçmişlerdir. Onların bu nifakları, küfürleri ve ilahi ahkamı tahrîfe cüretleri sebebiyle bu dünyada hüsrana uğrayacakları gibi ahirette de cehennemde ebedi kalacaklardır. ${ }^{100}$

Âyete bu şekilde yorum getiren Bilmen, tahrîf yapan kimselerin Yahûdîlerden bir kavim olduğunu ileri sürmüştür. Açıklamalarından yola çıkarak bu kavmin Yahûdîlerin alimleri olduğunu anlayabiliriz. Çünkü, o kavmin, kendilerine tabi olan kimselere dini ahkamı değiştirerek söylediklerini belirten Bilmen, tahrîfin Tevrât'ı bilen alimler tarafindan gerçekleştirildiğini ima etmiş olmaktadır. Burada dikkati çeken önemli bir konu Bilmen'in, yorumunda, sanki Maide 41. âyetin çevirisinin çevirisi gibi Kur'ân metnine bu kadar sadık kalması onu konuyla ilgili yorumlarında da kapalı kilmakta olduğudur.

99 Bilmen, Meali Âli, II, 767-769.

100 Bilmen, Meali Ali, II, 767-769. 


\section{SONUÇ}

Bu makalede müfessirlerin tahrîfle ilgili âyetleri yorumlamaları üzerinde durulmuştur. İlk dönemlerden itibaren farklı coğrafyalara müntesip müfessirlerin görüşlerine kısaca değinildikten sonra özellikle son dönem Türk müfessirlerin görüşlerine ağıllık verilmiştir. Türk müfessirlerin seleflerinden etkilenip etkilenmedikleri, Türk toplumunun son dönem Batı'yla temasından sonra mezkûr konu etrafinda geleneksel tefsîr çizgisinde bulunup bulunmadıkları incelenmeye çalışılmıştır. Müfessirler, tahrîfle ilgili âyetleri yorumlarken Kur'ân ve sünnet bütünlügüne bağl1 kalmışlar, ilk dönem müfessirleriyle son dönem müfessirleri arasinda tam bir muvafakat bulunmaktadır. Müfessirlerin çoğunluğu tahrîrifin hem lafiz (an mevadı ${ }^{\circ}$ ifadesinden) hem de manâda (min ba'di mevadı‘ ifadesinden) olduğunu kabul ederken daha çok manâ üzerinde yoğunlaşmaktadırlar. Dolayısıyla Tevrât, Zebur ve İncîl gibi kitaplarda her ne kadar lafzî tahrîf olsa da asıl tahrîfler yorumlardadır. Zaten mevcut olan durum da bunu desteklemektedir. Yaygin kanaate göre, Kur'ân'ın kastettiği Tevrât, - genel kaniya göre- bu gün kutsal kitap olarak kabul edilen Ahd-i Atîk'in çoz az bir kısmını oluşturmaktadır. Tahrîf edilen konular arasında da daha çok delâilü'n-nübüvvet üzerinde durulmuş, Hz. Peygamber'in nübüvvetini kabul etmemelerine vurgu yapılmıştır. Tarihsel süreç içerisinde de lafzî ve manevî tahrîf Hz. Mûsâ döneminde başlamış olup, Hz. Peygamber dönemine kadar devam etmiştir. Hz. Peygamber dönemine kadar tahrîfe uğramamış bazı hükümlerin de anlam olarak tahrîf edildiği görülür.

Makalede varılan diğer bir sonuç müfessirlerin (tahrîf kelimesi özelinde) daha çok Tevrât'ın tahrîfi üzerinde durmaları, Zebur'a hiç yer vermemeleri, İncîl'e ise çok az yer vermeleridir. Bunun sebepleri arasında Zebur ve İncîl'in şifahî olarak teblĭg edilmesi, Hz. Îsâ döneminden sonra yazıya geçirilmesi gösterilebilir. Diğer yandan Zebur'un tefsîrde fazla zikredilmemesi Kitab-1 Mukaddes içerisinde Tevrât kadar etkili olmamasından kaynaklanabilir. Bu nedenle ilgili âyetler genel olarak Yahûdîlerin kutsal metinler üzerindeki tahrîfinde yoğunlaşmaktadır. Burada kayda değer bir konu da; tahrîfi her iki din içerisinde de ileri gelen bir grubun yapmış olmasıdır. Diğer yandan ilgili âyetler tahrîfatın direk metin üzerinde olduğuna dair bir bilgi vermemektedir. Daha ziyade kutsal kitabın muhataplarının âyetlere yaklaşımı ve yorumlarıyla bir tahrîfatta bulundukları zikredilmektedir. Yani Kutsal kitaptan ziyade müntesiplerin tavrı önemlidir. Müntesipler düzgün olunca kitaplar da korunacak eğer düzgün olmazsa onların elindeki kitaba nasıl güvenilecektir.

Tahriff konusunda önemli bir nokta da müfessirlerin meseleye sadece âyetlerin tefsîri ve Kur'ân bütünlüğü içerisinde yaklaşmalarıdır. Kur'ân bütünlüğü göz ardı edilip sadece ilgili âyetleri açıklamak veya araştırmacıların 
dört âyete bağlı kalıp tahrîfi anlamak istemeleri büyük hata olacaktır. Tahrîfin müradifleri olan kelimelere de bakmak gerekir. Bu nedenle bu çalışmada tek başına eksik kalacağ1 düşüncesiyle devamı niteliğinde bir makale daha ele alınmış, bu makalede de tahrîfin müradifleri incelenmiştir. Hatta bununla da yetinilmeyip, tahrîfi anlamak Kur'ân bütünlüğü açısından ise daha faydalı olacaktır. Yine de biz Kur'ân bütünlügünü de aşarak, Kutsal kitap nüshalarının birbiriyle karşılaştırılmasını, daha sonra da bunların Kur'ân miyarından/mihenginden geçirilmesini öneririz. Çünkü Kur'ân, tahrîfle ilgili her yerde açık ve net bilgiler sunmayabilir. Onun hedefi hidayet ve ibrettir. Bundan dolayı da tahrîfi daha çok metinden ziyade muhataplar açısından ele almıştır. Yani Kur'ân, kutsal kitapların tahrîf şeklinden ziyade onun muhataplarının dine, Yüce Allah'a ve peygambere karşı tutumlarını hedef almakta, gelecek nesillere öğüt vermektedir. 


\section{KAYNAKÇA}

Kư'ân-1 Kerîm

Kitâb-1 Mukaddes

Adam, Baki, "Kur'ân'ın Anlaşılmasında Tevrât'ın Rolü", İslâmî Araşstrmalar Dergisi, c. 9, sy. 1- 4, Ankara 1996.

Adam, Baki, "Tevrât'in Tahrîfi Meselesine Müslüman ve Yahûdî Cephesinden Bir Bakış", Ankara İlabiyat Fakültesi Dergisi, sy. 36, Ankara 1997.

Adam, Baki, Yahûdî Kaynaklarnna Göre Tevrât, Pınar Yay., İstanbul 2001.

Ateş, Süleyman, “Tahrîf”, Kur'ân Ansiklopedisi, Kur'ân Bilimleri Araştırma Vakfi, İstanbul 1997.

Ateş, Süleyman, “Cennet Tekelcisi mi?”, İslâmî Araștrmalar, c. 4, sy. 1, Ocak 1990.

Ateş, Süleyman, Kur'ân-ı Kerim'in Evrensel Mesajina Cağrn, Birleşik Yay., İstanbul 1990.

Ateş, Süleyman, Yüce Kur'ân'ın Cağdaș Tefsîri, Yeni Ufuklar Neşriyat, İstanbul t.s.

Biçer, Ramazan, İslâm Kelâmcllarnna Göre İncîl, Gelenek Yay., İstanbul 2004.

Cüveynî, Şifâü'l-ğalil, thk. Michel Allard, Dâru'l-meşr1k, Beyrut 1968.

Dârimî, Sünen, "Mukaddime" 56, y.y. Dımeşk 1930, I, 163.

Dihlevî, Şah Veliyyullah, Fevæü'l-kebîr, çev. Mehmet Sofuoğlu, Çağr1 Yay., İstanbul 1980.

Ebû Dâvûd, Sünen, el-Mektebetü'l-İslâmiyye, İstanbul ts.

Elmallil, Hak Dini Kur'ân Dili, Azim Yay., İstanbul ts.

Gaudeul, J.M. - R. Caspar, "Kitab-1 Mukaddes'in Tahrîfi Konusunda Klasik İslami Kaynakların Yaklaşımı", çev. Ali Erbaş, Sakarya Üniversitesi İlabiyat Fakültesi Dergisi, sy. 7, Sakarya 2003.

Goldziher, Ignaz, "Ehl-i Kitaba Karşı İslâm Polemiği I" çev. Cihad Tunç, Ankara İlabiyat Fakültesi İslâm İlimleri Enstitüsü Dergisi, sy. 4, Ankara 1980.

Goldziher, Ignaz, "Ehl-i Kitaba Karş1 İslâm Polemiği II" çev. Cihad Tunç, Ankara İlabiyat Fakültesi İslâm İlimleri Enstitüsü Dergisi, sy. 5, Ankara 1982. 
Gökkır, Necmeddin, "Kur'ân-1 Kerîm Açısından İlahî Kitapların Tahrîfi Meselesi”, İstanbul Üniversitesi İlabijat Fakültesi Dergisi, sy. 2, İstanbul 2000.

Hâzin, Lübâbü't-te’vîl, Dâru'l-kütübi'l-1lmiyye, Beyrut 1415.

İbn Atıyye, el-Muharraru'l-vecî̌, Dâru'l-kütübi'l-1lmiyye, Beyrut 1422.

İbn Haldun, Kitâbü'l-iber, Dâru'l-kitâbi'l-Lübnânî, Beyrut 1956.

İbn Hazm, Kitâbül-fasl, Matbaatüll-Edebiyye, Kahire 1902.

İbn Manzûr, Lisânü'l-Arab, Dâru sâdır, Beyrut 1414.

İbn Sinâ, er-Risâletü'l-edhaviyye fi'l-meâd, y.y., 1969.

İbn Teymiyye, Cevâbü's-sabîh, Dâru'l-Âsıme, 1994.

İsfehânî, Ragıb, Müfredât, Safvân Adnan, Dâru'l-kalem-ed-Dâru'ş-şamiyye, Dimeşk-Beyrut 1412.

Makrîzî, Ahmed b. Ali, Hitat el-Makrîzî́, y.y., Kahire 1270.

Mâtürîdî, Ebû Mansur, Te'vîlatü̈ ebli's-sünne, Müessesetü’r-risâle, Beyrut 2004.

Muhammed Abdüh- Reşid Rızâ, Tefsiru'l-menâr, Dâru'l-ma'rife, Beyrut ts.

Ö. Nasuhi Bilmen., Kur'ân-ı Kerîm"in Türkse Meali Âlisi ve Tefsiri, Bilmen Yay., İstanbul ts.

Râzî, Fahruddîn, Mefâtîhu'l-ğgayb, Dâru ihyâi'l-türâsi'l-Arabî, Beyrut 1420.

Taberî, Câmiü'l-beyân, Müessesetü’r-risâle, Beyrut 2000.

Tarakçı, Muhammed, "Tevrât ve İncîl'in Tahrîfi ile İlgili Kur'ân Âyetlerinin Anlaşılması Sorunu" Usûl Dergisi, sy. 2, Adapazarı, 2004.

Vehbî Efendi, Hulâsatü'l-beyân, Üçdal Neşriyât, İstanbul 1966.

Yavuz, Salih Sabri-Yeniçağ, İbrahim, "Müslüman-Hıristiyan Polemiği Açısından Tahrîf”, Milel ve Nihal, cilt 6/sy 1, y. y. Nisan 2006.

Yıldırım, Arif, "Kelamî Açıdan Tevrât ve İncîlde Tahrîf Meselesi", Atatürk Üniversitesi İlahiyat Fakültesi Dergisi, sy. 26, Erzurum 2006.

Zemahşerî, Ebû Kasım Mahmûd b. Ömer, el-Keşşâf an hakâik ğavâmidit-tenzîl ve'luyûni'l-avâni'lfì vücûbi't-te'vîl, Dâru ihyâi't-türâsi'l-Arabî, Beyrut 1997. 